\title{
ANALISA PERBANDINGAN BERDASARKAN IDENTIFIKASI AREA KEBAKARAN DENGAN MENGGUNAKAN CITRA LANDSAT-8 DAN CITRA MODIS \\ (Studi Kasus : Kawasan Gunung Bromo)
}

\author{
Bangun Muljo Sukojo ${ }^{1}$, Nurul Aini ${ }^{1}$ \\ ${ }^{1}$ Departemen Teknik Geomatika, FTSLK-ITS, Kampus ITS Sukolilo, Surabaya, 60111, Indonesia \\ e-mail: ${ }^{1}$ bangun_ms@geodesy.its.ac.id
}

\begin{abstract}
Abstrak
Kebakaran hutan dan lahan adalah suatu keadaan di mana hutan dan lahan dilanda api, sehingga mengakibatkan kerusakan hutan dan lahan yang menimbulkan kerugian ekonomis dan atau nilai lingkungan. Pada musim kemarau, beberapa wilayah di Indonesia kerap mengalami kebakaran. Salah satu contohnya adalah kebakaran yang terjadi di kawasan Gunung Bromo pada tanggal 20 sampai 23 Oktober 2014. Kebakaran ini mengakibatkan kurang lebih 1.487 Ha hutan savana rusak terbakar. Daerah bekas terbakar dapat diidentifikasi dengan memanfaatkan data penginderaan jauh, seperti citra Landsat-8 dan citra MODIS. Metode identifikasi yang digunakan adalah metode NDVI (Normalized Difference Vegetation Index) yang memanfaatkan kanal inframerah dekat dan kanal merah. Daerah bekas terbakar diklasifikasi berdasarkan nilai dari tiga model threshold. Penggunaan beberapa model threshold dilakukan dengan tujuan mencari nilai akurasi paling besar. Berdasarkan hasil identifikasi daerah bekas terbakar, didapat nilai akurasi paling besar untuk citra Landsat- 8 adalah $48,394 \%$ dari model $\mu-1 \sigma$ dengan luas daerah bekas terbakar yang dihasilkan sebesar 1.354,5 Ha. Sedangkan nilai akurasi paling besar untuk citra MODIS adalah 57,089\% dari model $\mu$ dengan luas daerah bekas terbakar yang dihasilkan sebesar 1.005,209 $\mathrm{Ha}$.
\end{abstract}

Kata Kunci - Landsat-8, MODIS, NDVI, Threshold, Uji akurasi

\begin{abstract}
Land and forest fire is a condition where the land and forest are hit by flame, causing land and forest destruction, economic losses, and environmental value. In the dry season, some of the regions in Indonesia often hit by flame. One example is a fire that occurred in the area of Mountain Bromo on October, 20th to 23rd 2014. These fires resulted in approximately $1.487 \mathrm{Ha}$ of savanna forest got burned. Burned area can be identified by using remote sensing data, such as Landsat-8 and MODIS imagery. The method of identification used is the NDVI (Normalized Difference Vegetation Index) that utilizes near-infrared band and red band. Burned area is classified based on the value of the three threshold models. The use of multiple threshold models is done with the purpose of seeking the greatest accuracy value. Based on the results of burned area identification, obtained the greatest accuracy values of Landsat-8 is $48.394 \%$ from the $\mu-1 \sigma$ models and the wide of burned area is $1.354,5 \mathrm{Ha}$. While the greatest accuracy values of MODIS is 57,089\% from the $\mu$ models and the wide of burned area is 1.005,209 $\mathrm{Ha}$.
\end{abstract}

Key Words - Landsat-8, MODIS, NDVI, Threshold, Accuracy test

\section{PENDAHULUAN}

Kebakaran hutan dan lahan kerap terjadi di beberapa wilayah Indonesia. Salah satu contoh kasus kebakaran hutan dan lahan adalah kebakaran yang terjadi di kawasan Gunung Bromo pada tanggal 20 sampai 23 Oktober 2014. Kebakaran mengakibatkan kurang lebih $1.487 \mathrm{Ha}$ hutan savana rusak terbakar. Kondisi tersebut menggambarkan bahwa kebakaran dapat menjadi ancaman serius karena kerugian besar yang diakibatkannya. Oleh sebab itu, perlu dilakukan upaya penanganan pasca kebakaran dengan menyediakan informasi spasial daerah bekas terbakar dalam bentuk peta. Informasi dapat diperoleh dengan memanfaatkan data penginderaan jauh, yakni citra Landsat-8 dan citra MODIS.

Identifikasi daerah bekas terbakar dilakukan dengan menggunakan metode NDVI. NDVI (Normalized Difference Vegetation Index) merupakan indeks vegetasi yang menghasilkan citra representatif untuk analisa kerapatan vegetasi. NDVI memanfaatkan kanal inframerah dekat dan kanal merah yang memiliki kekontrasan 
tinggi untuk analisa kerapatan vegetasi. Metode NDVI dipilih karena resolusi spasial kanal yang digunakan sesuai dengan daerah penelitian yang kecil. Berdasarkan kanal yang digunakan, citra Landsat-8 memiliki resolusi spasial $30 \mathrm{~m}$ sedangkan citra MODIS memiliki resolusi spasial $250 \mathrm{~m}$

Perbedaan resolusi spasial citra Landsat-8 dan citra MODIS akan mengakibatkan perbedaaan hasil identifikasi daerah bekas terbakar yang berupa peta. Selain itu, perbedaan hasil juga dipengaruhi oleh model threshold yang digunakan. Identifikasi dilakukan dengan menggunakan tiga model threshold sehingga setiap citra menghasilkan tiga peta daerah bekas terbakar yang berbeda. Oleh karena itu, perlu dilakukan uji akurasi setiap model threshold dari citra Landsat-8 dan citra MODIS untuk mendapatkan hasil identifikasi daerah bekas terbakar dengan nilai akurasi paling tinggi.

\section{METODOLOGI PENELITIAN}

Lokasi penelitian berada di kawasan Gunung Bromo yang terletak pada tiga kabupaten yaitu Probolinggo, Malang, dan Pasuruan. Secara geografis terletak pada $7^{\circ} 56^{\prime} 30^{\prime \prime} \mathrm{LU} 112^{\circ} 57^{\prime} 00^{\prime \prime}$ BT. Kawasan Gunung Bromo berada di bawah pengelolaan Resort Tengger Laut Pasir, Taman Nasional Bromo Tengger Semeru.

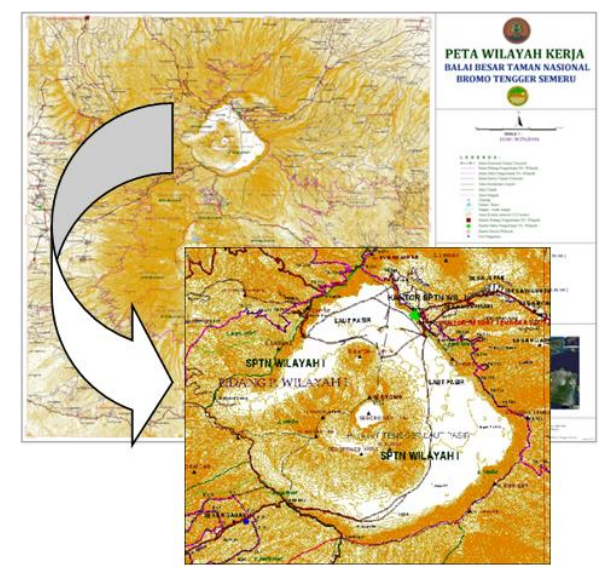

Gambar 1. Lokasi Penelitian

\section{Metodologi Penelitian}

Tahap Pengolahan Data

Tahap pengolahan data dalam penelitian ini adalah sebagai berikut :

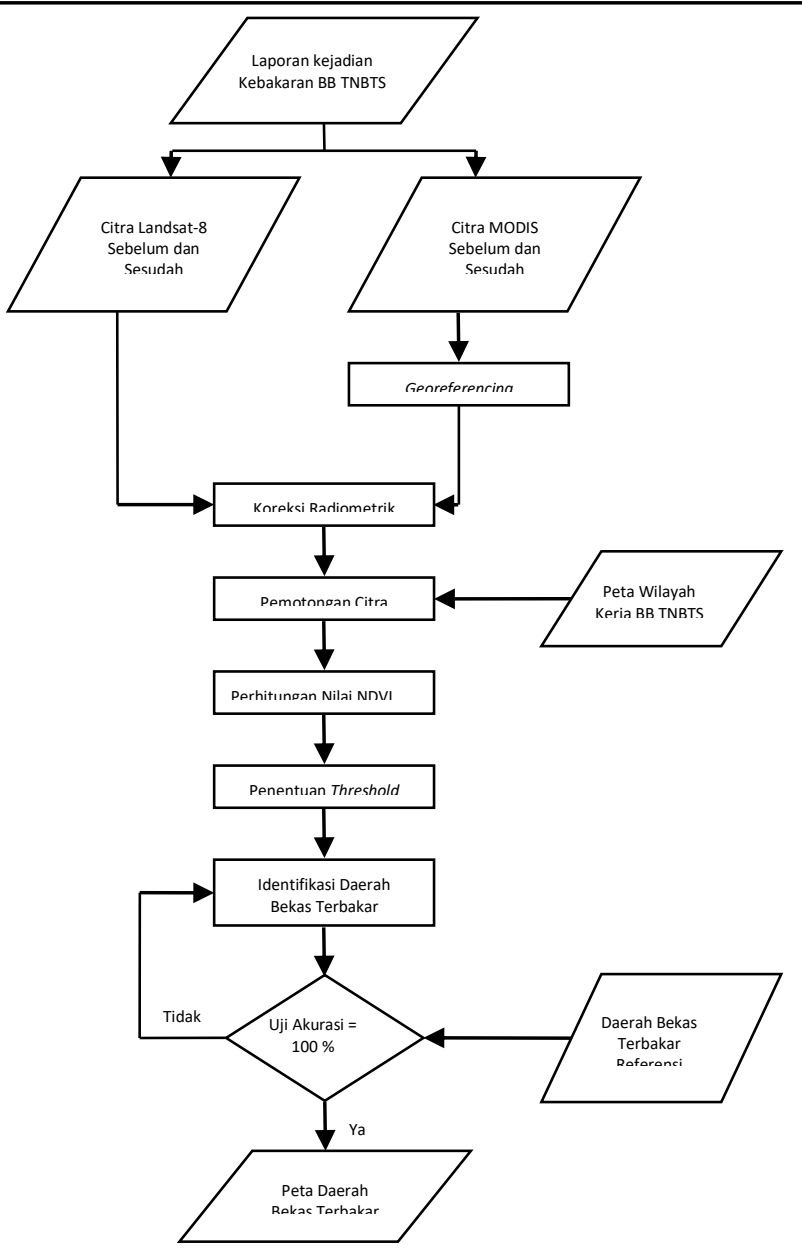

Gambar 3. Diagram Alir Pengolahan Data

Berikut penjelasan diagram alir pengolahan data :

1. Data Citra

Citra yang digunakan adalah citra Landsat-8 L1T dan citra MODIS Level 1B sebelum dan sesudah terjadinya kebakaran. Tanggal terjadinya kebakaran didapat dari laporan kejadian kebakaran BB TNBTS bulan Oktober 2014. Citra Landsat-8 yang digunakan adalah citra pada tanggal 3 Oktober 2014 dan 4 November 2014. Sedangkan citra MODIS yang digunakan adalah citra pada tanggal 27 Agustus 2014 dan 3 November 2014.

2. Georeferencing

Georeferencing merupakan proses pemberian sistem koordinat dari citra yang belum mempunyai acuan sistem koordinat ke dalam sistem koordinat dan proyeksi tertentu. Georeferencing hanya dilakukan untuk citra MODIS.

3. Koreksi Radiometrik

Koreksi radiometrik meliputi kalibrasi radiometric yang bertujuan untuk mengubah nilai Digital Number menjadi reflektan dan 
koreksi atmosferik yang bertujuan untuk menghilangkan efek atmosfer pada nilai reflektan citra.

4. Pemotongan Citra

Pemotongan citra dilakukan untuk mendapatkan daerah penelitian dan memfokuskan pengolahan data pada daerah tersebut. Citra dipotong berdasarkan area Seksi Pengelolaan Taman Nasional Wilayah 1 Resort Tengger Laut Pasir pada peta wilayah kerja BB TNBTS.

5. Perhitungan Nilai NDVI

NDVI (Normalized Difference Vegetation Index) merupakan indeks vegetasi yang menghasilkan citra representatif untuk analisa kerapatan vegetasi. NDVI juga dapat digunakan untuk mengidentifikasi daerah bekas terbakar. Persamaan NDVI berdasarkan metode Huete et al. (1999) adalah:

$N D V I=\frac{N I R-R e d(1)}{\text { NIR }+ \text { Red }}$

Perhitungan NDVI akan menghasilkan nilai $\mathrm{NDVI}_{1}, \mathrm{NDVI}_{2}$, dan $\triangle \mathrm{NDVI}$. NDVI ${ }_{1}$ dihitung dari citra sebelum kebakaran sedangkan $\mathrm{NDVI}_{2}$ dihitung dari citra sesudah kebakaran. $\triangle \mathrm{NDVI}$ dihitung dari persamaan berikut:

$\triangle N D V I=N D V I_{1}-N V_{2}(2)$

6. Penentuan Threshold

Threshold (nilai ambang batas) akan menentukan tingkat akurasi hasil daerah bekas terbakar. Penentuan threshold dilakukan dengan menghitung rata-rata $(\mu)$ dan standar deviasi $(\sigma)$ nilai reflektan citra sebelum dan sesudah kebakaran. Mengacu pada Fraser et al. (2000), model threshold yang akan digunakan adalah $\mu-1 \sigma, \mu, \mu+1 \sigma$.

7. Identifikasi Daerah Bekas Terbakar

Identifikasi daerah bekas terbakar dilakukan dengan menggunakan nilai $\triangle N D V I$ dan threshold. Persamaan untuk mendapatkan daerah bekas terbakar adalah:

$\mathrm{BA}=\Delta \mathrm{NDVI}>$ Threshold (3)

dimana BA adalah Burned Area (daerah bekas terbakar).

8. Uji Akurasi

Uji akurasi dilakukan dengan membandingkan hasil identifikasi daerah bekas terbakar (estimated burned area) dengan data daerah bekas terbakar referensi (referenced burned area). Berdasarkan data estimated burned area dan referenced burned area, dapat dihitung data valid, omisi, dan komisi. Data valid adalah data estimated burned area yang sesuai dengan referenced burned area. Omisi adalah burned area (pada estimasi) yang dinyatakan sebagai non-burned area (pada referensi). Komisi adalah non-burned area (pada estimasi) yang dinyatakan sebagai burned area (pada referensi). Uji akurasi dihitung dengan persamaan berikut (Lillesand \& Kiefer, 1994; Short, 1982; Jensen, 2005):

Akurasi $(\%)=\frac{V \times 100 \%}{V+O+K}$

Dimana $\mathrm{V}$ adalah data valid, $\mathrm{O}$ adalah data kesalahan omisi, dan $\mathrm{K}$ adalah data kesalahan komisi.

9. Peta

Informasi daerah bekas terbakar disajikan dalam bentuk peta yang sesuai dengan kaidah kartografi. Peta dibuat dari model threshold yang memiliki nilai akurasi paling besar.

\section{HASIL DAN PEMBAHASAN}

Daerah bekas terbakar referensi merupakan data acuan yang dijadikan patokan kebenaran hasil identifikasi daerah bekas terbakar dari citra Landsat-8 dan citra MODIS. Daerah bekas terbakar referensi didelineasi berdasarkan :

1. Interpretasi data secara manual

Daerah bekas terbakar diprakirakan dengan melakukan interpretasi citra satelit secara manual, yaitu kombinasi kanal citra Landsat 8. Adapun kombinasi kanal yang digunakan antara lain color infrared (vegetation), healthy vegetation dan vegetation analysis. Kombinasi kanal tersebut dapat digunakan untuk memperkirakan vegetasi yang sehat dan vegetasi yang tidak sehat (bekas terbakar).
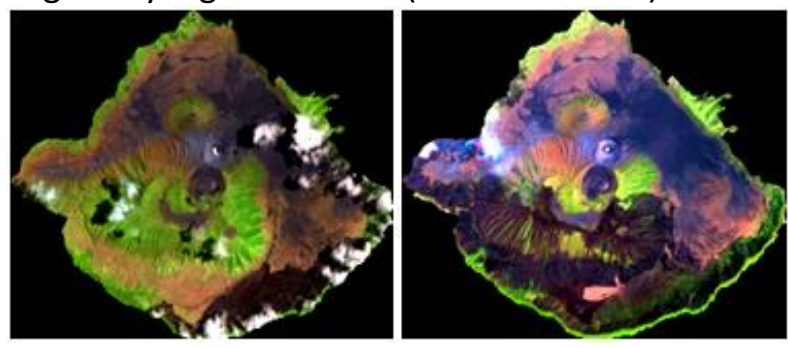

Gambar 4. Kombinasi Vegetation Analysis Citra Sebelum (a) dan Sesudah Kebakaran (b)

2. Laporan kejadian kebakaran Balai Besar TNBTS Laporan kejadian menyatakan telah terjadi kebakaran pada tanggal $20 \mathrm{~s} / \mathrm{d} 23$ Oktober 2014. Luas daerah yang terbakar $\pm 1.487 \mathrm{Ha}$ 
pada Blok Teletubbies, Gunung Watangan, Gunung Kursi, Adasan, dan Keciri yang berada di Wilayah Kerja Resort Tengger Laut Pasir.

Tabel 1. Koordinat Lokasi Daerah Bekas Terbakar Wilayah Kerja Resort Tengger Laut Pasir

\begin{tabular}{|c|c|c|}
\hline \multirow{2}{*}{\begin{tabular}{l}
\multicolumn{1}{c}{ Lokasi } \\
Blok Watu \\
Gedhe
\end{tabular}} & \multicolumn{2}{|c|}{ Koordinat } \\
\hline & $07^{\circ} 58^{\prime} 42.3^{\prime \prime} \mathrm{S}$ & $112^{\circ} 56^{\prime} 33.4^{\prime \prime} \mathrm{E}$ \\
\hline $\begin{array}{l}\text { Blok } \\
\text { Jemplang }\end{array}$ & $07^{\circ} 58^{\prime} 27.4^{\prime \prime} \mathrm{S}$ & $112^{\circ} 55^{\prime} 35.4^{\prime \prime} \mathrm{E}$ \\
\hline \multirow{2}{*}{$\begin{array}{l}\text { Blok } \\
\text { Teletubbies }\end{array}$} & $07^{\circ} 58^{\prime} 38.9^{\prime \prime} \mathrm{S}$ & $112^{\circ} 56^{\prime} 50.0^{\prime \prime} \mathrm{E}$ \\
\hline & $07^{\circ} 58^{\prime} 30.4^{\prime \prime} \mathrm{S}$ & $112^{\circ} 56^{\prime} 51.7^{\prime \prime} \mathrm{E}$ \\
\hline Blok Adasan & $07^{\circ} 58^{\prime} 30.4^{\prime \prime} \mathrm{S}$ & $112^{\circ} 57^{\prime} 17.2^{\prime \prime} \mathrm{E}$ \\
\hline \multirow{2}{*}{ Blok Pengol } & $07^{\circ} 58^{\prime} 14.5^{\prime \prime} \mathrm{S}$ & $112^{\circ} 57^{\prime} 48.6^{\prime \prime} \mathrm{E}$ \\
\hline & $07^{\circ} 57^{\prime} 50.7^{\prime \prime} \mathrm{S}$ & $112^{\circ} 58^{\prime} 01.7^{\prime \prime} \mathrm{E}$ \\
\hline $\begin{array}{l}\text { Blok } \\
\text { Gunung } \\
\text { Kursi }\end{array}$ & $07^{\circ} 57^{\prime} 14.2^{\prime \prime} \mathrm{S}$ & $112^{\circ} 57^{\prime} 58.9^{\prime \prime} \mathrm{E}$ \\
\hline
\end{tabular}

Berdasarkan hasil interpretasi dari kombinasi kanal Landsat-8 dan data koordinat lokasi daerah terbakar, maka dapat dibuat peta daerah bekas terbakar referensi seperti berikut :

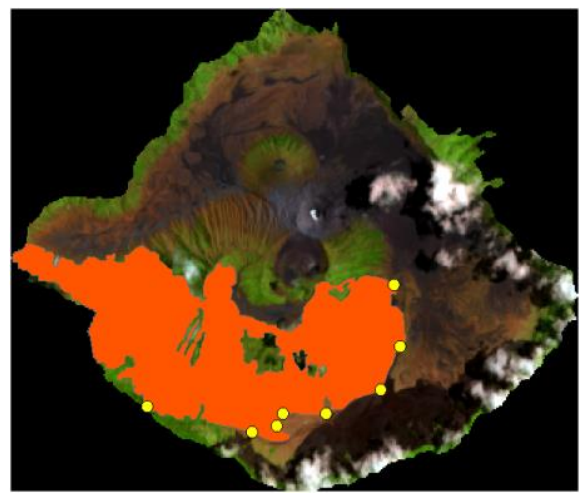

Gambar 5. Daerah Bekas Terbakar Referensi

1. Data citra

Citra yang digunakan adalah citra Landsat-8 dan citra MODIS sebelum dan sesudah terjadinya kebakaran. Tanggal terjadinya kebakaran didapat dari laporan kejadian kebakaran Balai Besar TNBTS, yaitu 20 sampai 23 Oktober 2014.

- Citra Landsat-8

Level : $1 T$

Sebelum kebakaran : 3 Oktober 2014

Sesudah kebakaran : 4 November 2014

- Citra MODIS

Level: 1B

Sebelum kebakaran: 27 Agustus 2014

Sesudah kebakaran : 3 November 2014

2. Georeferencing
Georeferencing merupakan proses pemberian sistem koordinat dari citra yang belum memiliki sistem koordinat ke dalam sistem koordinat dan proyeksi tertentu. Geo-referencing hanya dilakukan untuk citra MODIS yang sudah memiliki data geolokasi.

3. Koreksi radiometric

Koreksi radiometrik meliputi kalibrasi radiometrik yang bertujuan untuk mengubah nilai Digital Number menjadi reflektan dan koreksi atmosferik yang bertujuan untuk menghilangkan efek atmosfer pada nilai reflektan citra.

4. Pemotongan citra

Pemotongan citra dilakukan untuk mendapatkan daerah penelitian dan memfokuskan pengolahan data pada daerah tersebut. Citra dipotong berdasarkan area Resort Tengger Laut Pasir pada peta wilayah kerja Balai Besar TNBTS.

5. Perhitungan nilai NDVI

Perhitungan NDVI akan menghasilkan nilai $\mathrm{NDV}_{1}, \mathrm{NDVI}_{2}$, dan $\triangle \mathrm{NDV}$. NDVI ${ }_{1}$ dan $\mathrm{NDVI}_{2}$ dihitung dengan persamaan 1 sedangkan $\triangle N D V I$ dihitung dengan persamaan 2. Nilai NDVI berada dalam kisaran -1 hingga +1 .

Tabel 2. Nilai NDVI

\begin{tabular}{l|l|l}
\hline \multirow{2}{*}{ NDVI } & \multicolumn{2}{|c}{ Citra } \\
\cline { 2 - 3 } & \multicolumn{1}{|c}{ Landsat-8 } & \multicolumn{1}{|c}{ MODIS } \\
\hline \multirow{2}{*}{$\mathrm{NDVI}_{1}$} & $0,02364 \mathrm{~s} / \mathrm{d} 1$ & $\begin{array}{l}-0,22391 \mathrm{~s} / \mathrm{d} \\
0,48277\end{array}$ \\
\hline \multirow{2}{*}{$\mathrm{NDVI}_{2}$} & $-0,02915 \mathrm{~s} / \mathrm{d}$ & $-0,27899 \mathrm{~s} / \mathrm{d}$ \\
& 0,97704 & 0,38253 \\
\hline \multirow{2}{*}{$\Delta \mathrm{NDVI}$} & $-0,83966 \mathrm{~s} / \mathrm{d}$ & $-0,39777 \mathrm{~s} / \mathrm{d}$ \\
& 0,92125 & 0,58749 \\
\hline
\end{tabular}

Peristiwa kebakaran akan mengubah tutupan lahan dari vegetasi menjadi lahan terbuka dan menyisakan bekas kebakaran. Perubahan tersebut mempengaruhi hasil perhitungan NDVI. Lahan bervegetasi memiliki nilai NDVI lebih besar dibandingkan lahan terbuka bekas kebakaran. Sehingga terjadi penurunan nilai NDVI pada daerah tertentu sesaat setelah kebakaran.

Tabel 3. Rata-rata Nilai NDVI Sebelum dan Sesudah Kebakaran

\begin{tabular}{c|l|l}
\hline \multirow{2}{*}{ NDVI } & \multicolumn{2}{|c}{ Citra } \\
\cline { 2 - 3 } & \multicolumn{1}{|c}{ Landsat-8 } & \multicolumn{1}{c}{ MODIS } \\
\hline$\mu \mathrm{NDVI}_{1}$ & 0.438901 & 0.143328 \\
\hline$\mu \mathrm{NDVI}_{2}$ & 0.339704 & -0.038138 \\
\hline
\end{tabular}

6. Penentuan threshold 
Penentuan threshold dilakukan dengan menghitung rata-rata $(\mu)$ dan standar deviasi $(\sigma)$ nilai reflektan dari 50 titik sampel citra Landsat-8 yang dianggap terbakar. Nilai ratarata dan standar deviasi yang dihasilkan adalah 0.32002748 dan 0.116521449 . Nilai threshold yang dihasilkan adalah:

$$
\begin{array}{ll}
\mu-1 \sigma & =0.203506031 \\
\mu & =0.320027480 \\
\mu+1 \sigma & =0.436548929
\end{array}
$$

Setiap titik sampel memiliki nilai reflektan yang berbeda. Nilai tersebut menunjukkan tingkat keparahan daerah bekas terbakar. Semakin besar nilainya semakin parah. Oleh sebab itu, pemilihan titik sampel sebaiknya dilakukan di daerah bekas terbakar yang parah dan tidak. Jumlah titik sampel juga mempengaruhi nilai threshold. Semakin banyak titik sampel semakin baik nilainya.

7. Identifikasi daerah bekas terbakar Suatu piksel dinyatakan sebagai daerah bekas terbakar jika nilainya melebihi nilai threshold. Identifikasi daerah bekas terbakar referensi (estimated burned area) dilakukan dengan menggunakan persamaan 3. Berikut hasil klasifikasi daerah bekas terbakar dari model threshold yang digunakan:

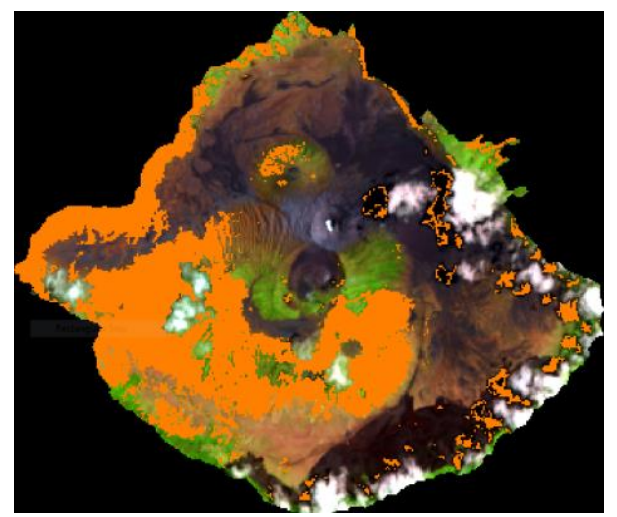

Gambar 6. Model $\mu-1 \sigma=0.203501$ dari Citra

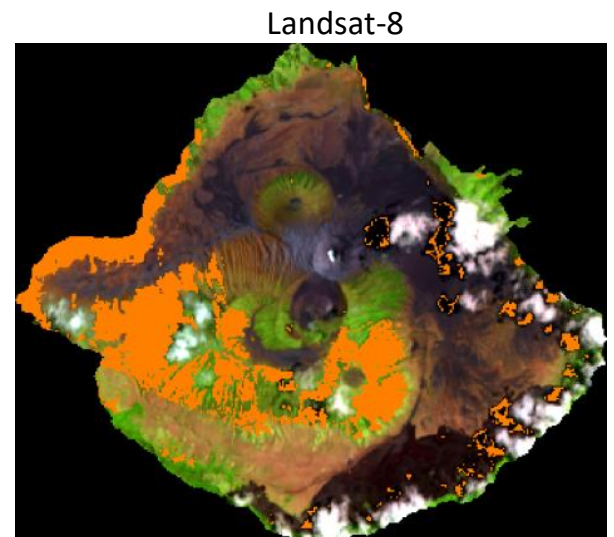

Gambar 7. Model $\mu=0.32003$ dari Citra Landsat-8

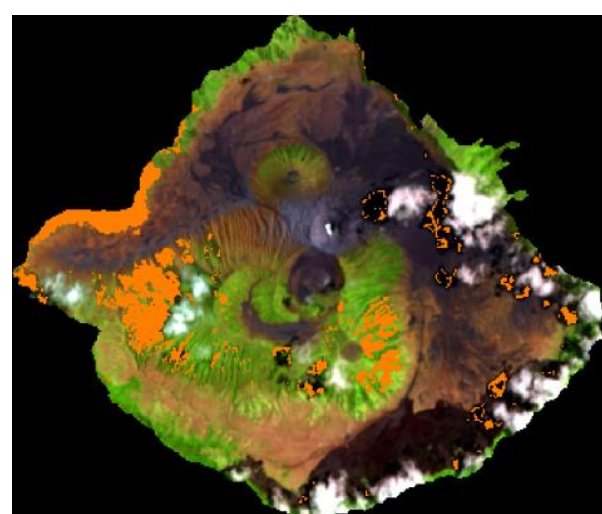

Gambar 8. Model $\mu+1 \sigma=0.43655$ dari Citra Landsat-8

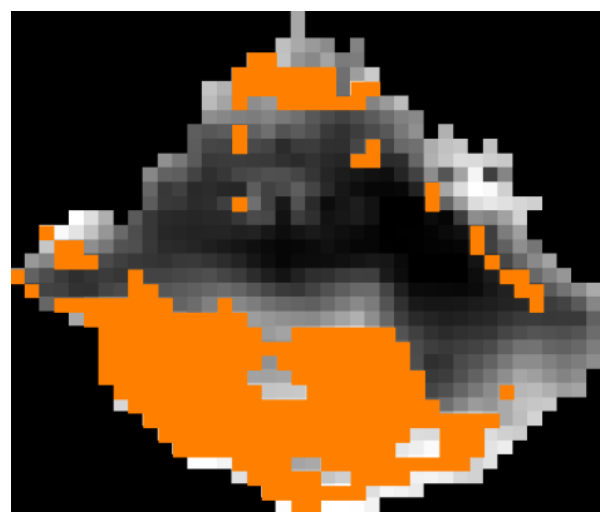

Gambar 9. Model $\mu-1 \sigma=0.203501$ dari Citra MODIS

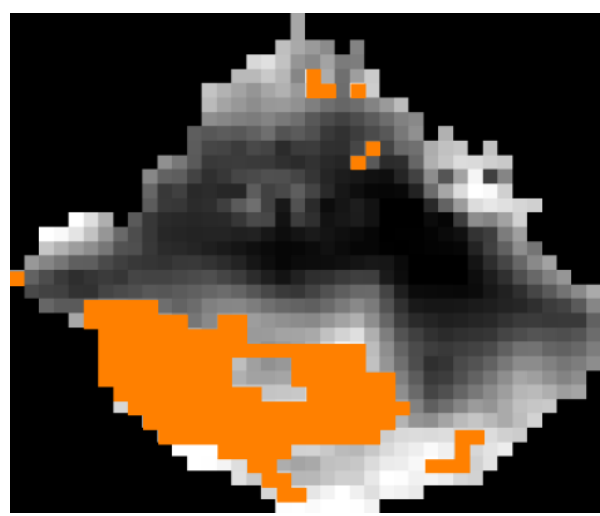

Gambar 10. Model $\mu=0.32003$ dari Citra MODIS

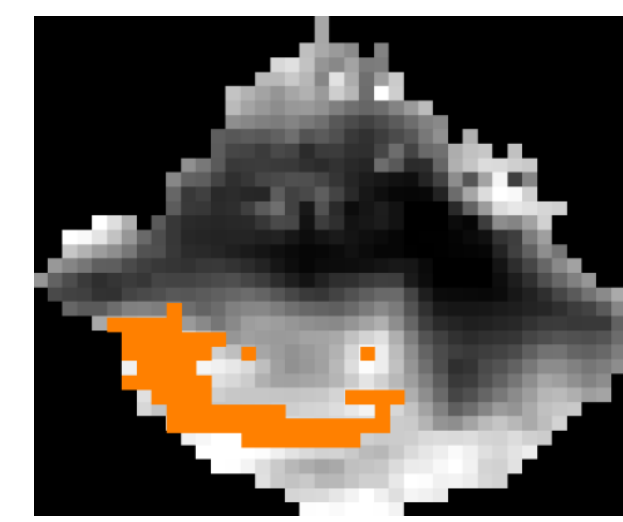

Gambar 11. Model $\mu+1 \sigma=0.43655$ dari Citra MODIS 
Hasil klasifikasi daerah bekas terbakar dipengaruhi oleh nilai threshold. Semakin kecil nilanya, semakin banyak piksel yang dinyatakan sebagai daerah bekas terbakar. Begitupun sebaliknya. Meskipun nilai threshold yang digunakan pada citra Landsat-8 dan citra MODIS sama, luas daerah bekas terbakar yang dihasilkan berbeda. Hal ini disebabkan oleh perbedaan resolusi spasial keduanya.

Citra Landsat-8 memiliki resolusi spasial $30 \mathrm{~m}$ sedangkan citra MODIS memiliki resolusi spasial $250 \mathrm{~m}$. Berdasarkan resolusi spasialnya, luas terkecil daerah bekas terbakar yang masih dapat terdeteksi (satu piksel) adalah $900 \mathrm{~m}^{2}$ dan 62500 $\mathrm{m}^{2}$. Namun, tidak berarti seluruh daerah dalam satu piksel tersebut merupakan daerah bekas terbakar. Bisa jadi daerah bekas terbakar kecil (kurang dari satu piksel) yang terdeteksi sebagai daerah bekas terbakar satu piksel penuh.

Tabel 4. Luas Daerah Bekas Terbakar

\begin{tabular}{c|c|c}
\hline \multirow{2}{*}{ Threshold } & \multicolumn{2}{|c}{ Luas Daerah Bekas Terbakar } \\
\cline { 2 - 3 } & Landsat-8 & MODIS \\
\hline$\mu-1 \sigma$ & $\mathbf{1 . 3 5 4 , 5 ~ H a}$ & $1.751,432 \mathrm{Ha}$ \\
\hline$\mu$ & $794,79 \mathrm{Ha}$ & $\mathbf{1 . 0 0 5 , 2 0 9 \mathrm { Ha }}$ \\
\hline$\mu+1 \sigma$ & $357,12 \mathrm{Ha}$ & $437,848 \mathrm{Ha}$ \\
\hline
\end{tabular}

\section{Analisa akurasi}

Uji akurasi dilakukan dengan membandingkan hasil identifikasi daerah bekas terbakar (estimated burned area) dengan data daerah bekas terbakar referensi (referenced burned area). Daerah bekas terbakar diprakirakan dengan melakukan kombinasi kanal citra Landsat8 dan pengecekan koordinat lokasi daerah bekas terbakar dari laporan kejadian kebakaran BB TNBTS. Berdasarkan prakiraan tersebut, dapat dibuat daerah bekas terbakar referensi (referenced burned area) dengan melakukan delineasi.

Berdasarkan data estimated burned area dan referenced burned area, dapat dihitung data valid, omisi, dan komisi.

Tabel 5. Data Valid, Omisi, dan Komisi

\begin{tabular}{c|c|c|c|c}
\hline Citra & $\begin{array}{c}\text { Threshol } \\
\boldsymbol{d}\end{array}$ & Data Valid & Omisi & Komisi \\
\hline \multirow{4}{*}{$\begin{array}{c}\text { Landsa } \\
\text { t } 8\end{array}$} & $\mu-1 \sigma$ & $837,997 \mathrm{Ha}$ & $516,503 \mathrm{Ha}$ & $\begin{array}{c}377,094 \\
\mathrm{Ha}\end{array}$ \\
\cline { 2 - 5 } & $\mu$ & $520,364 \mathrm{Ha}$ & $274,426 \mathrm{Ha}$ & $\begin{array}{c}694,728 \\
\mathrm{Ha}\end{array}$ \\
\cline { 2 - 5 } & $\mu+1 \sigma$ & $206,519 \mathrm{Ha}$ & $150,601 \mathrm{Ha}$ & $\begin{array}{c}1.008,572 \\
\mathrm{Ha}\end{array}$ \\
\hline \multirow{2}{*}{ MODIS } & $\mu-1 \sigma$ & $969,504 \mathrm{Ha}$ & $781,928 \mathrm{Ha}$ & $\begin{array}{c}245,587 \\
\mathrm{Ha}\end{array}$ \\
\cline { 2 - 5 } & $\mu$ & $806,896 \mathrm{Ha}$ & $198,314 \mathrm{Ha}$ & 408,196 \\
\hline
\end{tabular}

\begin{tabular}{c|c|c|c|c}
\hline & & & & $\mathrm{Ha}$ \\
\cline { 2 - 5 } & $\mu+1 \sigma$ & $420,574 \mathrm{Ha}$ & $17,274 \mathrm{Ha}$ & $\begin{array}{c}794,518 \\
\mathrm{Ha}\end{array}$ \\
\hline
\end{tabular}

Besar nilai akurasi dipengaruhi oleh nilai omisi dan komisi. Pada tabel di atas, nilai omisi dan komisi citra Landsat-8 dan citra MODIS terbilang cukup besar. Hal ini disebabkan oleh adanya tutupan awan dan bayangannya sehingga mempengaruhi nilai perekaman citra yang dihasilkan. Tutupan awan mengakibatkan suatu daerah tidak terdeteksi sebagai daerah bekas terbakar, sedangkan bayangannya mengakibatkan sutau daerah terdeteksi sebagai daerah bekas terbakar. Nilai akurasi dihitung dengan persamaan 4 .

Tabel 6. Nilai Akurasi

\begin{tabular}{c|c|c}
\hline \multirow{2}{*}{ Threshold } & \multicolumn{2}{|c}{ Nilai Akurasi } \\
\cline { 2 - 3 } & Landsat-8 & MODIS \\
\hline$\mu-1 \sigma$ & $\mathbf{4 8 , 3 9 4 \%}$ & $48,548 \%$ \\
\hline$\mu$ & $34,935 \%$ & $\mathbf{5 7 , 0 8 9 \%}$ \\
\hline$\mu+1 \sigma$ & $15,122 \%$ & $34,127 \%$ \\
\hline
\end{tabular}

Nilai akurasi paling besar untuk citra Landsat- 8 adalah $48 \%$ dari model $\mu-1 \sigma$ dan untuk citra MODIS adalah $57 \%$ dari model $\mu$.

9. Peta daerah bekas terbakar

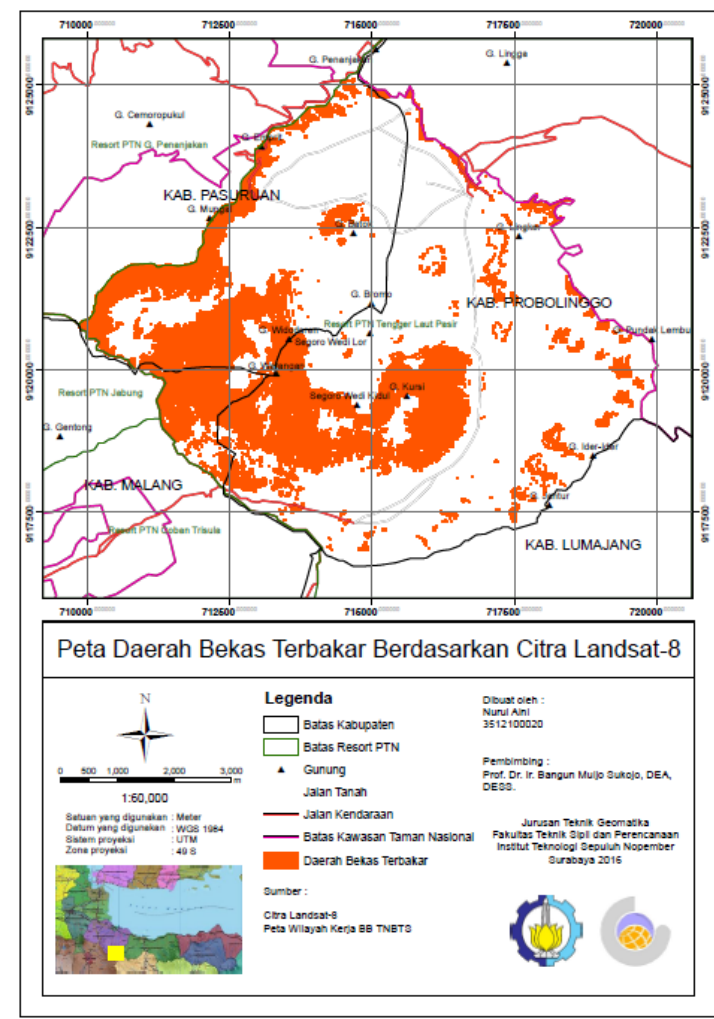

Gambar 12. Peta Daerah Bekas Terbakar Berdasarkan Citra Landsat-8 


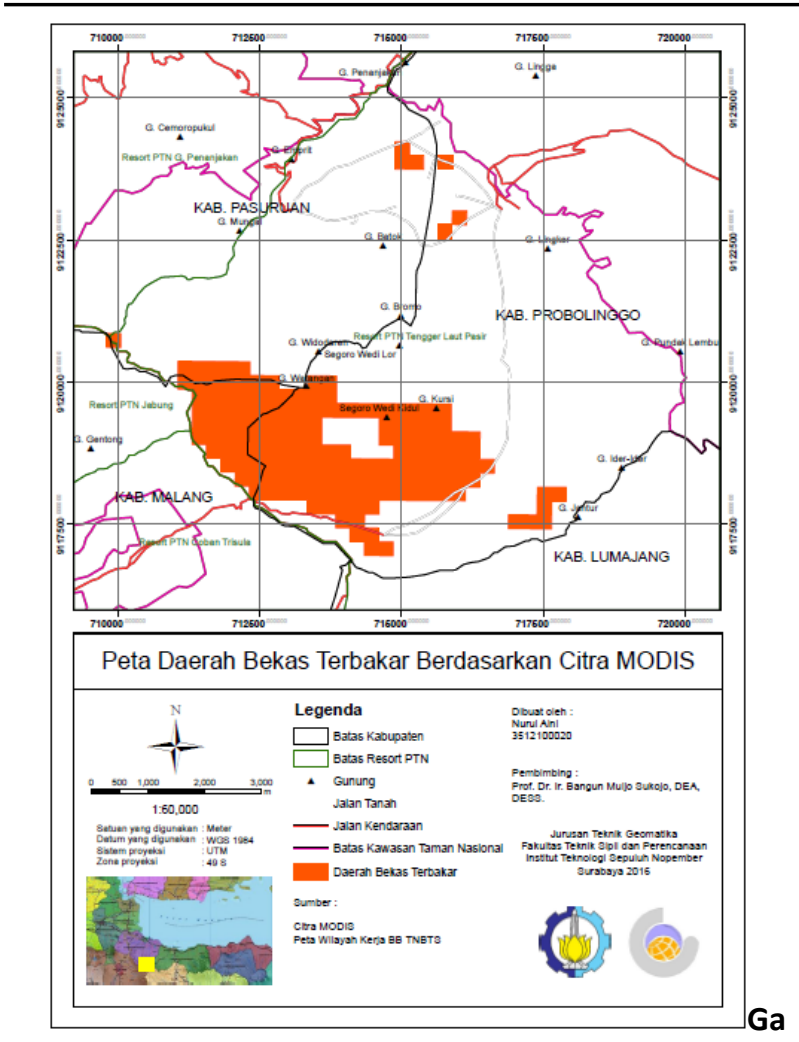

Gambar 13. Peta Daerah Bekas Terbakar Berdasarkan Citra MODIS

\section{KESIMPULAN}

Berdasarkan hasil yang didapatkan dari penelitian maka penulis menyimpulkan bahwa:

1.Luas area terbakar hasil klasifikasi citra landsat $830 \mathrm{~m}$ adalah $125.923,790$ Hektar dengan nilai luasan terbesar berada pada Kabupaten Bengkalis dengan area terbakar seluas 40.011,077 Hektar dan nilai luasan terkecil berada pada Kabupaten Rokan Hulu seluas 47,950 Hektar.

2.Luas area terbakar hasil klasifikasi citra MODIS $250 \mathrm{~m}$ adalah 171.045,154 Hektar dengan nilai luasan terbesar berada pada Kabupaten Bengkalis dengan area terbakar seluas 58.502,386 Hektar dan nilai luasan terkecil berada pada Kabupaten Rokan Hulu seluas 281,250 Hektar.

3.Berdasarkan hasil penilaian akurasi dari citra MODIS dan citra Landsat 8 didapatkan hasil luas burned area agreement 40.200,882 Hektar, related comission error 94.633,149 Hektar, related omission error 44.744,897 Hektar, independent comission error 23.165,602 Hektar, dan independent ommission error 21.766,780 Hektar.

\section{UCAPAN TERIMA KASIH}

Kami sampaikan terima kasih kepada kepada Departemen Geomatika ITS yang telah memberikan dukungan administrasi dan pendanaan sehingga penelitian ini dapat berjalan dengan baik dan lancar.

\section{DAFTAR PUSTAKA}

Artha, F. 2011. Studi Perbandingan Sebaran Hotspot dengan Menggunakan Citra Satelit NOAA/AVHRR dan AQUA MODIS. Surabaya: Institut Teknologi Sepuluh Nopember.

Badan Nasional Penanggulangan Bencana, 2015. Definisi dan jenis bencana, <URL : http://bnpb.go.id/pengetahuan-bencana/definisidan-jenis-bencana>. Dikunjungi pada tanggal 1 November 2015, jam 19.00.

Fraser, R.H., Li, Z., \& Cihlar, J., 2000. Hotspot and NDVI Differencing Synergy (HANDS):ANewTechniqueforBurnedAreaMapping Over Boreal Foresy, Remote Sensing of Environment,72, 362-376.

Huete, A., Justice, C., \& Leeuwen, V.W.,1999. Modis Vegetation Index(MOD 13) Algorithm TheoreticalBasis Document, University ofVirginia,DepartmentofEnvironmentalSciences, Cha rlottesville, Virginia.

Pusat Pemanfaatan Penginderaan Jauh LAPAN. 2005. Pedoman Pemanfaatan Data landsat-8 untuk Deteksi Daerah Terbakar (Burned Area).

Suryo, Bagus, 2014. 10 Hari Terbakar, 400 Hektare Savana Gunung Bromo Terbakar, <URL : http://news.metrotvnews.com/read/2014/10/22/3 08651/400-hektare-savana-gunung-bromo-terbakar >. Dikunjungi pada tanggal 1 November 2015, jam 20.20.

Suwarsono. 2012. Daerah Bekas Kebakaran Hutan dan Lahan (Burned Area) di Kalimantan. Depok : Universitas Indonesia. 